\title{
日本の河川平野部における礫の円形度についで
}

\section{中山正民** •三浦敏彦***}

\begin{abstract}
摘要 河川に扔ける磨滅・運搬過程を知る一方法として, 安倍川・大井川・木曾川・長良川・物部川・揖斐 川・庄川・手取川・犬上川・日野川の 10 河川における平野部分で, 数種の $32 \sim 16 \mathrm{~mm}$ 磞を用いて, 円形度 を測定し，その変化及び原因の考察を行なつた。

各河川とも，円形度の変化は㗂質によって異り，石灰岩礫は急激に円形化するのに，チャート礫はほとん ぞ円形化が進まず，岩質による磨滅に著しく差異のあることを示す。また花崗岩・粘板岩・頁岩等は, その 剝離性質のため, 分裂・粉䂶作用を受けやすい.

最も多くの河川に存在する砂岩礫を用いて, 円形化の原因を考察すると, 河床勾配の急な河川ほど, 急激 なことがわかる。しかし, 流域面積に比して, 河川幅員の非常に広い大井川では, 平均円形度は上流から下 流へかけてほとんど変らず, 磞の磨滅に対して, 乱流が大きな役割をはたしていることを示す。

䃯の重量が減少する割合は河川の性質・運搬距離・磉質などによつて異るが, 円形度を利用した推定結果 では，わが国の河川砂磷は，一般的には渓口までで $7 \%$, 䂺の分布限界あるいは河口まで $9 \%$ 程度減少する ようである.ささらに, これを基とした粒径変化に含まれる磨滅作用の割合は, 平野部分では $2 \%$ \%゙で, 残 りの $98 \%$ は㔍分作用によるものと考えられる。

円形度の変化から, 磨滅作用に対する岩石抵抗の関係を求めると, チャート・石英斑岩・流紋岩・砂岩・ 花崗岩・頁岩・粘板岩・石灰岩の順に弱くなる。
\end{abstract}

\section{I 緒 言}

箨者の 1 人中山は, 多摩川 州川・天竜川ふ3どの河川において，各種粒径の砂 㗂を用いて円形度4の測定を行ない，これによつて， 河川における砂櫟の磨隇・運搬過程の一部分を明ら かにした。しかし，現在のところ，この方面の研究 はあまり行なわれていず，未知の部分がなお非常に 多い.

たとえば，河床勾配と砂礫の円形度の変化との関 係については，一応急勾配の河川ほど，急激に变化 することが，かなり明らかにされている5).しかし，
この関係はわずか 4 河川の結果から得たもので，完 全な法則とするには，今後さらに多くの河川にあた つてみる必要がある。

このほか，今までほとんど研究が進んでいないも のに，礫質による磨減の差異がある。この問題につ

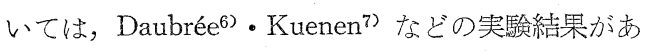
るが，実際の河川ではどの程度であるか，全く不明 である、この問題は河川に括ける砂樂の大きさの減 少とも，大きな関係があるので，実際河川における 研究結果が非常に必要である。

以上述べた問題を発展させる目的で，今回は礫の 供給の少ない，多くの平野河川老対象として研究を

* 本研究の要点は，1963 年度日本地理学会春季大会で発表した。**大阪学芸大学 *** 城東工業高校

1）中山正民（1954）：多摩川に打る礫の円形度について，地理評，27，497〜506.

2）中山正民（1960）:2３ の河川における礫の円磨度について，大阪学芸大学紀要A－9，139～156.

3）中山正民（1963）：天竜川・野州川における河川礫の円形度に関する研究，大阪学芸大学紀要 $A-11$, $120 \sim 135$.

4）從来の研究では円磨度という術棓を使用した。しかし原語 roundness 意味しかないので，三野教授の御注意によつて円形度と改称することにした。

5）前揭 2)，3）

6) Daubrée, A. (1879) : Études synthétiques de géologie expérimentale, 2.

7) Kuenen, ph. H. (1956) : Experimental abrasion of pebbles, 2, Rolling by current, Jour. Geol., 40, $443 \sim 451$. 


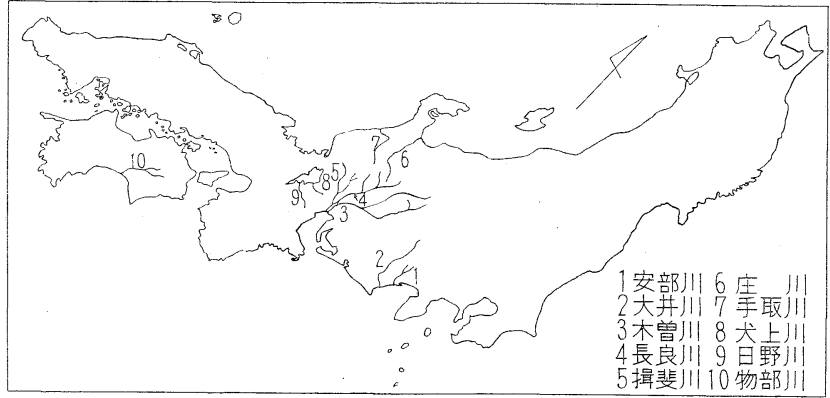

第 1 図 調 查 河川

定地域は各河川とも，従来の研究と同 じく，側壁や支流から礫の供給が少な い平野地域に限つた。各河川の調查地 域における諸性質を示すと，第 1 表の ごとくである。

測定を行なつた場所は各河川とも大 体 $2 \sim 3$ 地点とした。 もちろんこのよ うな少数の地点では，諸性質の変化を， 正確につかむことはむつつかい，しか

行なつた。この場合，従来の研究に比して，河川に おける測定地点の数が少ないため，变化の精度は多 少劣るけれども，より多くの河川で，より多くの就 質を用いて測定を行なつたので，かなり新しい專夷 を知ることが出来た。

\section{II 測定河川及び測定方法}

本研究のため，新たに測定を行なつた河川は，東 海地才の安倍川・大井川・木兽川・長良川・揖斐川・ 北陸地厅の庄川・手取川，近江盆地の犬上川・日野 川，四国の物部川の 10 河川である（第 1 図）．測 第 1 表 测定河川の諸性質

\begin{tabular}{c|c|c|c}
\hline 河川名 & 測定距離 & 河川勾配 & 平均河川幅* \\
\hline 安倍川 & $\mathrm{km}$ & $\times 10^{-3}$ & $\mathrm{~m}$ \\
大井川 & 9.3 & 5.3 & 610 \\
木曾川 & 14.2 & 4.6 & 860 \\
長良川 & 15.9 & 2.1 & 670 \\
揖斐川 & 9.8 & 2.7 & 280 \\
庄 川 & 18.8 & 3.3 & 440 \\
手取川 & 9.8 & 4.7 & 510 \\
犬上川 & 5.3 & 7.1 & 340 \\
日野川 & 10.5 & 3.6 & 170 \\
物部川 & 9.5 & 2.7 & 150 \\
* 平均河川幅 & 4.0 & 440
\end{tabular}

* 平均河川幅は測定区閒 4 地点の平均
し従来の研究結果から，砂砅の供給地域から離れた 平野河川では，ほぼ直線的に増加することが明らか

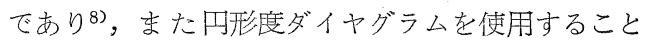
である程度離れた地点 ${ }^{9}$ で円形度を測定すれば， 多少精度が悪くとも，大まかな変化は推定できるも のと考えた。

次に今回の研究では，円形度の測定は32〜16 mm に限定した。一般に 32〜16 mm礫の円形度は，より 大きな $64 \sim 32 \mathrm{~mm}$ 樂の值に等しいか，あるいはにれ に近い值をとり，その変化は $64 \sim 32 \mathrm{~mm}$ 礫の場合に 近い10).これに対して，より小さな砂は，変化が明 瞭でなく, 河川による差異が少ない。このほか 32〜 $16 \mathrm{~mm}$ 礫は，最も容易に集めることができ，測定に 便利である. 以上のことから，32〜16 mm礫は，河 川で最も測定しやすく，かつより大きな礫の磨隇過 程を推定するのに最も便利な階級であるように思わ れる。

磁質は，その河川で最も顕著なもの $2 \sim 3$ 種類を 選んだ。このように，大まかに顕著なものを選ぶこ とが，その河床に含まれる礫の何\%を選んだかを， 大井川及び犬上川の 2 地点で調查した(第 2 図).こ の図によると，犬上川の腤色の纅中に，白色の石灰

\footnotetext{
8）前揭 2)，3）. 平均円形度の変化は，最初は急激，その後は非常にゆるやかである.しかし，これは笑験， あるいは礫の供給地が局限されている単純な場合に限られるようである。

9）少なくとも $4 \mathrm{~km} く$ らい.

10）前揭 2)，3）
} 


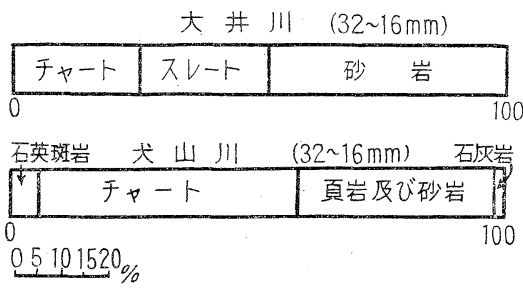

第 2 図 鿬質構成状態

䇹皪がある場合を除けば,顕著な 2 ～種の䃯で，そ の地点に含まれる全䊧質の $80 \%$ 近くを選ぶことが わかる、したがつて，いわゆる顕著な礫を取上げ， その円形度を測定することにより，その河川におけ る砂礫全体の磨滅状態は，ほ注推定できそうである。

円形度の測定方法その他については，以前の研究 と同様である11)。

\section{III 各河川に特ける磁質別の平 均円形度と距離との関係}

礫質別の平均円形度と距離との関係・四形度ダイ ヤグラム文び粒径ダィヤグラムを河川別にまとめ， 考察を行なうと次のごとくである.

\section{1 安倍川}

測定区域は静岡市下与衛門新田から，河口の同市 浜村までで， $9.6 \mathrm{~km}$ の間に 3 測定地点を設けた。 この測定地域における各要素の変化は，第 3 図のご とくである．粒径ダイヤグラムによると，各扗点と も最大粒径は 128～64 mm で，測定区域全般にわた つて，その割合は変らない。

安倍川の上流地域における地質は，静岡大学地学
教室によつて，主に古第

三系の砂岩及び粘板岩か らなつていることが明ら かにされている12). そし

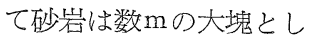
て河川に供給されるが， 粘板岩は細粒物質として 供給され，これが下流に おいて，大礫は潘とんど 砂岩で，粘板岩は細粒制 しかみられないといつた 分布に現らわれている13. このような地質状態から， 粘板岩と砂岩とは，ほほ

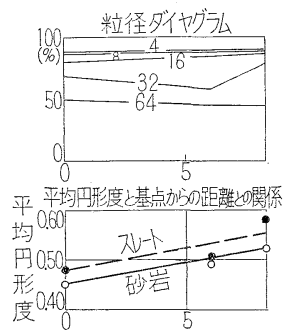

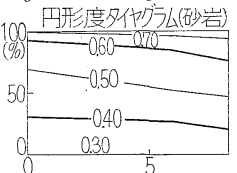

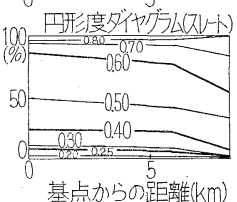

第 3 図安倍川 同一地点 ${ }^{14)}$ から供給されたとみなすことができる. したがつて，第1地点における粘板岩と砂岩の平均 円形度の差は，両者の磨隇の差を示すものであろ 5.

測定区域では，第 2 地点のやや上流で，支流の夢 科川が合流する。この河川の礫も，多くは第三系の 砂岩や粘板岩の礫であるが，そのほかチャート礫が みられる、したがうて第 2 地点や第 3 地点では，橖 科川の堆積物による影響を考えねばならぬ。しかし， 橖科川で測定した砂岩の平脍円形度は，第 2 地点に おける平均円形度に近いことから ${ }^{15)}$ ，第 2 ・第 3 地 点でも菜科川の影響による值の変化は，現らわれな いものと考えた ${ }^{16)}$.

平均门形度と距離との関係をみると，全体として，

11）前揭 2).この研究でも述べた如く，まつたく磨滅を受けない角礫の円形度を $0.10 \pm 0.05$ とするためには， 測定図の中径は 20〜 $40 \mathrm{~mm}$ でなければならない。このため筆者は，ほとんどすべて投影図の中径を 30〜 $40 \mathrm{~mm}$ として測定した。

12）静岡大学地学教室 (1956): 静岡県の地質, 静岡県

13）町田 洋（1959）：安倍川上流部の推積段丘一荒廃山地にみられる急速な地形変化の 1 例，地理評，32， $520 \sim 531$.

14）本研究では，各河川とも，測定地点は上流から下流へ，第 1 ，第 2 ，第 $3 ， \cdots \cdots$ とする.

15）㩰科川に打ける砂岩の平均円形度は 0.51 であるのに対し，安倍川第 2 地点に抢ける砂岩のそれは 0.49 でありあまり大きな差はないものと考えた。 
粘板岩のほうが砂岩よりやや高くなつている。この 場合，砂岩の平均门形度は，下流方向へ澌増する傾 向がみられるのに対して，粘板岩の変化はやや異な つている。すなわち第 2 地点に打ける粘板岩の平均 円形度は 0.49 で，第 1 地点の 0.48 とほとんど変わ らないが，第 3 地点では 0.59 と急激に増加する. このように各地点で值の変動が著しい傾向は，次の 大井川に打ける真岩でもみられるから，これは粘板 岩・頁岩にみられる一般的傾向と考えな。

円形度ダイヤグラムによると，砂岩と粘板岩とで は，その内容が相当に買なつていることがわかる。 すなわち平均门形度の高い粘板岩では，0.80といつ た非常に磨隇された礫が存在する反面, 砂岩には全 くみられない，0:25より低い亜角礫も10\%程度存 在している。このように粘板岩の平均凹形度が砂岩 より高いにかかわらず，砂岩にはみられない低い值 の礫がかなりあるのは，粘板岩が軟いため，磨滅が 急速に進む反面，剝離的性質によつて，䃯相互が衝 突する際，粉砕・分裂作用を受けやすいことを示す むのであるら。

\section{2 大半川}

大井川の測定区域は。静岡県溙原郡金谷町横岡か ら，河口近くの太平橋に至る $19.2 \mathrm{~km}$ の部分である。 この区域における諸要素は第 4 図のごとくであり， 第 1 均点には 256〜128 $\mathrm{mm}$ の戀がみられるが，こ の階級は第 2 地点から下流には存在せず，河床状熊 がやや変つていることを示古。

測定区域から上流の地質については，最近静岡大 学地学教室によつて調查され, 古生層の砂岩・頁 岩・チャート，及び時代未詳の中生層である三倉層 の砂岩・頁岩が，広い面積を占めていることが明ら
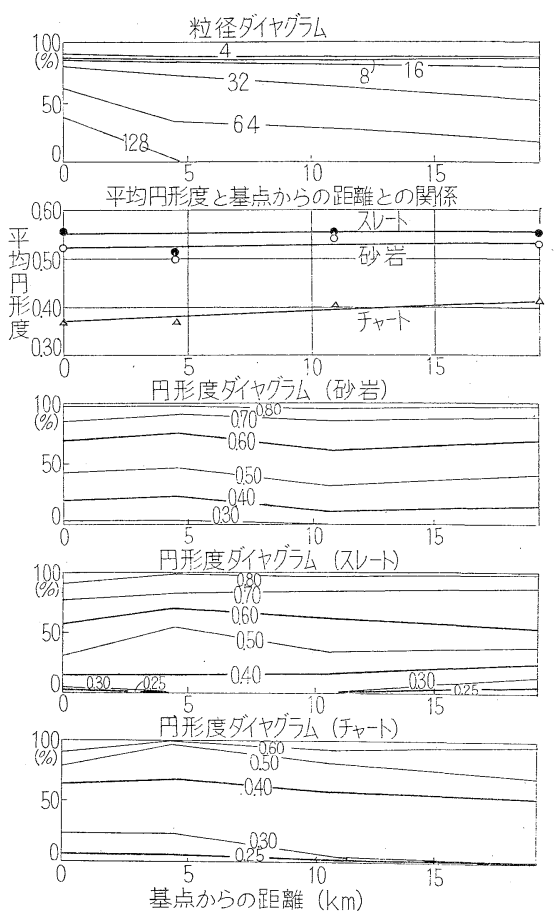

第 4 図大井川

かにされている17)。この地質状態から，大井川に招 いては，砂岩と頁岩とは住地全域から供給されるの に対し，チャートは最上流部からのみ供給されるこ とになる。この意味からすれば，第1地点における 円形度は，砂岩・頁岩では低いものが多く，チャー トでは高いものが多いはずである.

しかし，円形度ダイヤグラムによると，そのよう な傾向はみられず，砂岩・頁岩を゙は $0.40 よ り$ 低い 樂が $20 \%$ 程度あるのに対して，チャートでは 0.40 より低いものが $60 \%$ 程度もあり，半ば以上の礫 が磨滅が進まず，存棱を有していることがわか る18). これはチャートが磨隇に対する抵抗力強いこ とを意味するものである。したがつて，第 1 地点に おける平均门形度の差異は，礫の磨滅に対する抵抗

16）粘板岩の平均円形度の差異も考えねばなら妨，後述のごとく，この岩石は值の変動が著しいので，吟 味はしなかつた。

17）前揭 12) 
の差異によつて生じたものと考えられる。

第 1 地点から下流に抢ける砂岩・チャートの平均 円形度は，その変化が非常に少なく，下流方向へわ ずかに増加しているに過ぎない。頁岩も，全体とし ては，ほとんど変化がないが，第 2 地点のみは，他 の地点よりかなり低い值を示している。このように， 頁岩の平均円形度が，地点によつてかなり著しく変 動するのは，安倍川における粘板岩と同にくく，礫質 が崩䱋しやすいためであろう。これ㥧岩の円形度 ダイヤグラムからもよくわかる

砂岩・頁岩・チャートの平均円形度は, 全体とし て頁岩のそれが最も高く，次いで砂岩，チャートが 最も低い。この場合，頁岩と砂岩の平均口形度の差

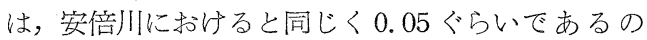
で，この值をある程度運搬された，頁岩と砂岩との 磨隇の差と考えた。

\section{3 木兽川}

木曽川における測定地点は，渓口の犬山付近にあ るライン大橋近くとそそれより $15.9 \mathrm{~km}$ 下流にあた る，一宮市の名鉄本線鉄橋付近との 2 個所である. この 2 地点における，粒径ダイヤグラムは第 5 図の ごとくで，犬山付近には $256 \mathrm{~mm}$ 以上，あるいは

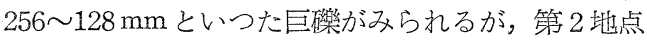
では $128 \mathrm{~mm}$ より大きな䃯はなく，この 2 つの地点 で，粒径はかなり減少していることがわかる。

木曽川では，砂岩樂と石英斑岩碟との円形度を測 定した。犬山より上流地域の地質を概略的にみると， 次のごとくである ${ }^{19)}$. すなわち，本流及び最も大き な支流の飛驒川とも，広い範囲にわたつて，古生層 文び石英斑岩や流紋岩などの火成岩が分布している.

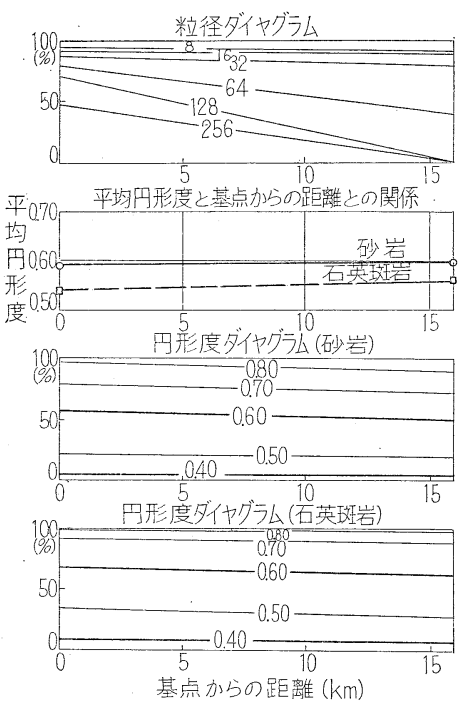

第 5 図本兽川

この場合，本流は最上流地域に古生憬，それより下 流に火成岩が分布しているが，飛驒川は区対で，最 上流地域に火成岩，下流部分が古生層となつている. したがつて，大まかに考えれば，木曾川では，この $2 つ の$ 岩質の礫は，同じ距離だけ運搬されたものと みなすことができる。このように考えると，犬山に おける平均円形度で，石英坟岩より砂岩のほうがや や高いのは，石英斑岩の才が砂岩より磨隇されにく い結果と考えた。このことは，実験結果ともよく一 致する20).

犬山攻び一宮における，平均円形度と距離との関 係から，木曽川中・下流区域に掞いては，平均円形 度は長い間運搬されても，ほとんど变化しないと思 われる．このことは，円形度ダイヤグラムで，砂岩 も石英斑岩も，各陛級の割合が㴗とんど変らないこ とからも明瞭である. 従つて，犬山から下流では， 礫はほとんど磨滅しないものと考えることができる。

18）角棱は最も磨滅を受けやすい部分である。この部分が磨滅しないのは，碟それ自身の抵抗が強いか，磨 滅作用が弱いかである。大井川の上流地域は，高度 $3000 \mathrm{~m}$ 以上もある壮年山地であるから，磨滅作用が弱 いとは考えられない。

19）藤本治義・鹿沼茂三郎・猪郷久義（1962）：飛驒山地の上部古生界について，飛驒山地の地質研究.

20）前揭 7） 
次に，木曾川における砂岩の円形度多イヤグラム と，天竜川に打ける砂岩のそれとを比較すると，両 者は非常によく似て戈り，各階級の割合もほぼ同一 と考光られる21)。竜川甘木曽川も，わが国では大 河川といわ扎るものであること加考光ると，各地 点に抢ける円形度のヒストグラムは，かなり長距離 運搬された砂岩のタイプとみなすことができる。

\section{4 長良川}

長良川における測定は，上流は岐㚖市郊外の上芥 見，下流は岐㚖市内の長良橋と忠節橋との間の 2 地 点で行なつた。両地点間の距離は $8.8 \mathrm{~km}$ あ。. 湘定 した 2 地点間における粒径ダイヤグラムは，第 6 図 のごとくである.これによると，第1地点では 256 mmより大きな纅があるが，第 2 地点では 256〜128

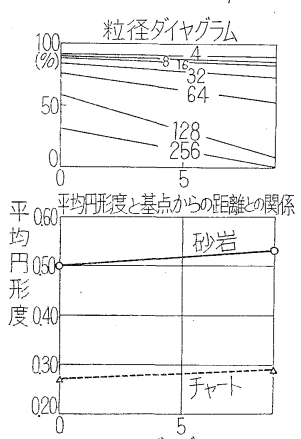
$\mathrm{mm}$ が最も大きな階級で あり，測定区間で粒径が やや減少すると考えられ る.

長良川では，砂岩と チャートとを測定した. 長良川上流地域には，秩 父古生層が広く分布して いる222。しかし，長良川 の平野部にみられるチャ 一ト礫の大部分は，関市 南方で合流する津保川か ら供給されたものである. この河川は，流域の起伏 がささ，また比較的短 基点加の距敨( $(\mathrm{km})$

第6 図 長良川
ため23)，チャート礫は ほとんぞ磨滅されずに 長良川に流入している。 第 1 地点に抢ける，于 ヤートの平均円形度が， 砂岩のそれに比べて， 他の河川の場合よりか なり小さいのはこのた めである24).

第 1 地点と第 2 地点 とで，平均円形度を比 較すると，砂岩・チャ ートとも，第 2 地点に 扒汀る平均円形度は僅

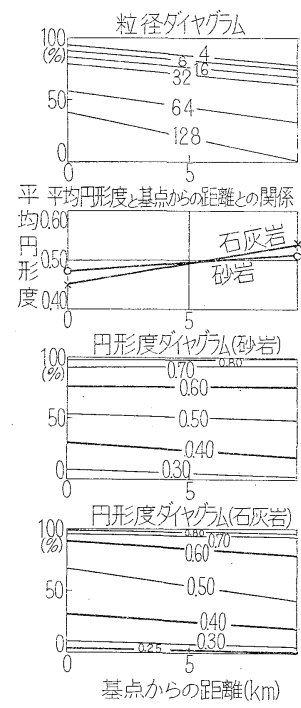

策 7 図 揖悲川 かながら増加している。このような円形度がやや増 加する傾向は，円形度ダイヤグラムでもかなり明瞭 に認められるので，長良川の測定区域では各省質と も僅かながら磨隇が進行しているものと考えた。

\section{5 揖 斐 川}

揖斐川では，上流側は岐阜県撮斐郡揖斐川町前島。 下流側は同県安八郡神戸町落合の 2 地点で測定を行 なつた．上流地点と第 2 地点との距離は $9.5 \mathrm{~km}$ で ある、この両地点における粒径ダイヤグラムその他， は，第 7 図のごとくである.この図によると，第1 地点では 256 ～ $128 \mathrm{~mm}$ の礫が存在するが，第 2 地 点では $128 \mathrm{~mm}$ より大きな礫は存在せず，この間で かなり大きく粒径が減少していることがわかる.

揖斐川では砂岩碟と石灰岩礫とを測定した。第 1 地点より上流における地質については，長良川の場 合と同じく，藤本治義らによつて，詳しく調査され，

21）前揭 3). 22） 前揭 19）

23）長良川本流は関市より上流が約 $60 \mathrm{~km}$ あるに対し，津保川の上流部は 20 数 $\mathrm{km}$ に過ぎない.

24）砂岩とチャートの平均円形度の差は，大井川では約 0.15 であるのに対し，長良川では約 0.25 もあり,か。 なり大きく違っている. 
ている25). それによると。この河川の流域は，砂 岩・粘板碞・チャート等よりなる二畳系の根尾層が 広く分布し，局地的に凝灰岩・チャート・石灰岩上 りなる，同じ二畳柔の丹生川層がある。この場合， 丹生川層第 1 地点よりやや上流，及び上流の撮斐 郡徳山村開田付近のみにみられる。第 1 地点におけ る平均四形度方石灰岩より砂岩のほうが高いのは， 砂岩のほうが遠距離にわたつて，運搬されたためで あろら・

第 1 地点と第 2 地点とにおける平均门形度を比較 すると，砂岩は長良川の場合と同じようにわずか に増加しているに過ぎないが，石灰岩はこれに比較 すると，増加する割合が大きく，砂岩より磨滅され やすいことを示す。この状態を円形度ダイヤグラム によつて調べると，石灰岩は第 1 地点から第 2 地点

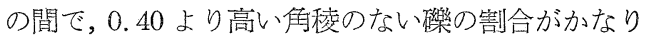
増加している。これは石灰岩の磨滅過程が，危稜だ けでなく，全面にわたる研磨作用によつて，急激に 進むことを意味し，石兏岩が磨隇されやすい性質を よく示している.

\section{6 庄 川}

庄川における測定区域は，庄川扇状地の扇頂にあ る富山県東砺波郡庄川町金屋加 ら，北陸本線の鉄橋 付近までの延長 $18.8 \mathrm{~km}$ で，ここに 3 地点を設け測 定を行なつた。測定区間における諸変化は第 8 図の ごとくである。粒径ダイヤグラムによつて河床状態 をみると，第 1 地点には $256 \mathrm{~mm}$ より大きな巨碟が 非常に多く，また第 2 ・第 3 地点にも $256 \sim 128 \mathrm{~mm}$
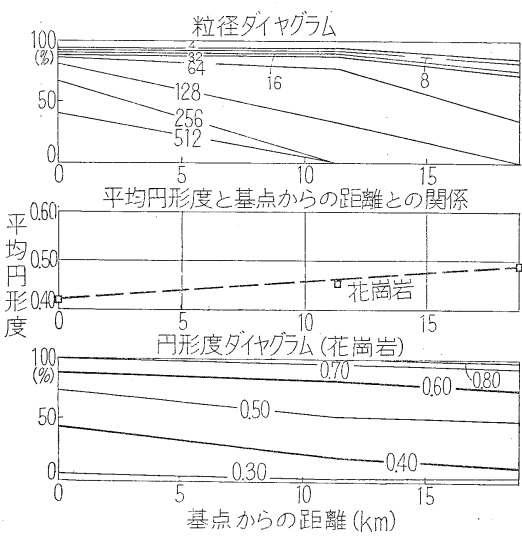

第 8 図庄玔

の礫がかなり存在しているから，営力の強い地域で あると考えることができる。

第 1 地点より上流における地質構造は，飛驒带及 び新期の花崗岩類が大部分を占めている26)。したが

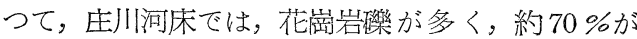
この種の礫よりなつている．庄川に於いては花崗岩

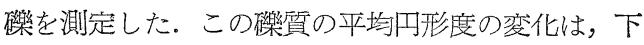
流方向にかなり增加している。しかし，一般に花崗 岩は非常に磨隇が早いものという概念から考えれば， この変化は営力の強いわりにさほど磨隇の早いこと を示すものではない27).ただ円形度ダイヤグラムに よると，角稜をもつ 0.40 より低い酻が次第に少な くなるにかかわらず，0.25より低い亜角礫は僅かで はあるが各地点で認められるし，反対に非常に円磨 された 0.60 より高い絤もかなりみられる.これは 花崗岩が，磨隇しやすい反面，崩壊しやすい性質を もつことを示すものと思われる.

25）前揭 19）

26）橿山次郎（1951）：日本地方地質誌中部地方.

27）庄川に於ける花崗岩の平均円形度の变化は，入間川に括ける硬砂岩の場合と同じである。河床勾配・粒 径分布その他から，庄川のほうが入閒川より磨滅営力が強いと思われるにもかかわらずこのように变化 が同じなのは，花崗岩と啋岩との抵抗が等しいか，或いは花崗岩のほうがむしろ大きいことを示すように 思われる。しかし，円形度ダイヤグラムからみると，花崗岩のほうに円形のものが多いから，ここでは花 菵岩と砂岩との磨滅が等しいか，或いはやや花崗岩のほうが早いと考えた。 


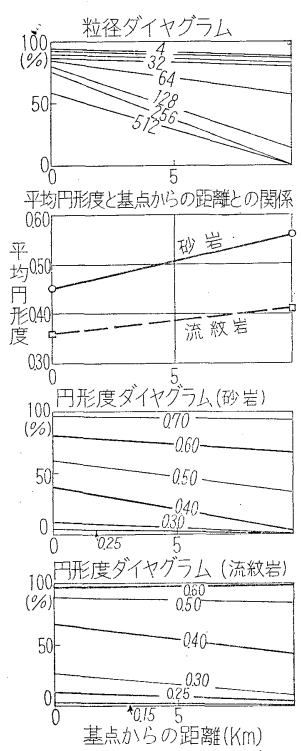

第 9 図手取川

\section{7 手取 川}

手取川では，手取扇状 地の扇頂にあたる，石川 県石川郡鶴来町の天狗橋 付近と，下流の国道 8 是 線にかかる手取大橋付近 とで測定を行なつた。両 地点の距離は $9.8 \mathrm{~km}$ で ある。手取川上流地域の ほぼ半ばは，中生層の手 取層群と飛驒変成岩が広 い面積を占め，それより 下流地域には古第 3 紀に 噴出した流紋岩や安山岩 などが分布している28 。

手取川では砂碧と流紋岩とを測定した。測定区間 における粒径ダイヤグラム，平均円形穈と距離との 関係，文び円形店ダイヤグラムは第 9 図のごとくで ある．粒径ダイヤグラムによつて，手取川の河床状 態を考察すると，第 1 地点には 1024～512 mm の巨 礫が多いし，第 2 地点でも 512～256 $\mathrm{mm}$ 程度の䃯 はかなりみられる。また測定区域の河床勾配も非常 に急である．以上のことを考え合すと，この区間の 運搬営力は非常に強いむのと想像される.

第1地点に执いて，砂岩の平均口形度が流紋岩の それより高いのは，運搬距離の影響によることが大 きいためと考えた。平均円形度と距離との関係は， 砂岩・流紋岩とも，かなり著しくその值が増加して いる.とくに砂岩皪の増加の割合が著しく，今まで 測定した河川の中では，最も変化が大きい。これに 対し，流紋岩礫の增加は，砂岩に比べるとかなり少 ない。したがつて，流紋岩は砂岩に比して磨隇し難
い岩石といえる.

このことは円形度ダイヤグラムによつても認めら れる.すなわち，流紋岩は砂岩に比べて，0.40より 低い絲の割合が多く，その割合はあまり変らない。 角稜は最も磨滅克受けやすいものであることから考 えるとこのように磨滅作用が強いにかかわらず， 角稜の多い絸が多いことは，礫の磨滅しにくいこと を示すものであろう。

\section{8 犬上川}

犬上川では，旧中山道にか かる無賃橋と，湖岸とで測定 を行なつた。両地点間の距離 は $5.3 \mathrm{~km}$ ある.第 1 地点から 第 2 地点へかけての粒径ダイ ヤグラムその他は，第10図の ごとでくある. 粒径ダイヤグ ラムによると，犬上川のこの 区域に打ける最大粒径は 128 〜64mm であり，砂の割合も 多い。

この河川上流の地質は，滰 本清 290 の研究文び $1 / 50$ 万地磒 図によつて，秩父古生層の于 ヤート及び石灰岩と石英班岩 とからなつていることが眀ら かにされている. そして，こ の場合石英斑岩礘の運搬距離 が長く，チャートや石灰岩碟 の運搬距離が短かいことが， 第 1 地点のごとき比較的抵抗 の強い石英斑岩が，抵抗の弱 い石灰岩よりも平均口形度が
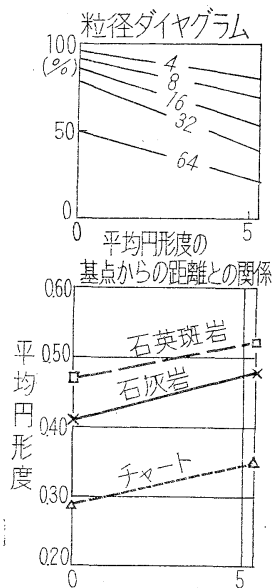

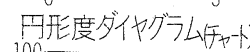
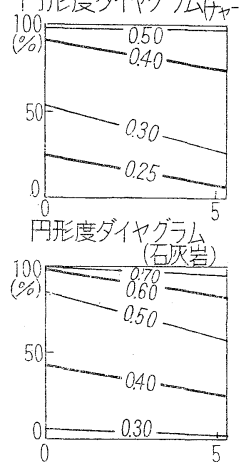

円形度ダイヤ゙ラム

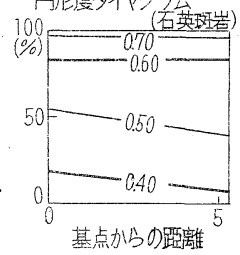

第10図 犬上川
円形度ダイヤグラム

28）前揭 26)

29）滰本 清（1936）：泣賀県犬上郡霊仙山付近の地質構造，地球，26，1～11. 
高くなる原因なのであるろ。

第 1 地点と第 2 地点との間で，平均凹形度の変化 を比較すると，各暞質ともかなり増加しておりここ の币でも石灰岩の増加が大きいようである．このよ うに，石灰岩礫の磨滅方著しいのは，他の河川と同 じく，石灰岩が他の岩質に比して磨隇されやすいた めであろう，各岩質とも円形度ダイヤグラムによる と，0.40より低い礫は，次第に少なくなる傾向をも つから，田削，研磨作用による磨隇が進んでいるも のと思われる。

\section{9 日野川}

日野川の測定区域は，滋賀県蒲生郡蒲生町桜川か ら同郡竜王町に至る $10.5 \mathrm{~km}$ の部分である。この河 川の上流部の地質については，1/50万地質困以外に 詳しい報告はなく，秩父古生層が広く分布する事が

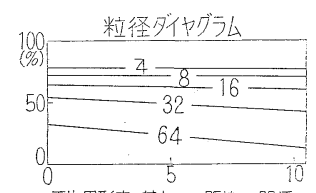

平均
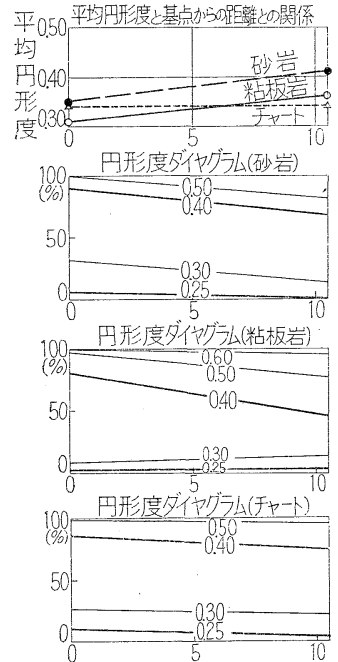

基点加方距離 $(\mathrm{km})$

第 11 図 日野川
わかるのみで，岩石の種 類・分布は不明である。

この河川では，粘板 岩・础岩・チャートの礫 について测定を行なつた (第11図)。この場合， 前述のごとく岩石の詳し い分布がわからないので， 第 1 地点でチャートの平 均円形度が，砂岩のそれ より高い理由は不明だあ る。しかし，大井川・安倍 川における粘板岩・頁岩 と砂岩の平均口形度の差 が，日野川のそれとよく 似ていることから考える と，粘板岩と砂岩はほぼ
同じ位置に分布しているのに対し，チャートはそれ より上流に分布していることを示すものであろう。

日野川の測定区域における諸要素の変化をみると 測定区域に拈ける最大級の礫は 128～64 mm である が，砂の量が $10 \%$ 程度もあり，砂量の多い河川と いうことができる。砂量の多少は，礫の磨滅に対し

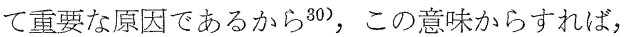
日野川では円形度が变化しないように考えられる。 しかし，この河川でも，チャ一ト在除く粘板岩・砂 岩の平均円形度は，第 2 地点ではわりあい高くなつ ており，砂の割合が礫の磨隇に対して，あまり重要 な因子であるとは考えられない。

粘板岩と砂岩との円形度の割合を，円形度名イヤ グラムで比較すると，全体として粘板岩のほうが円 形度の高いものが多いが，その反面 0.25 より低い 亚角砅もみられる。このことは安倍川・大井川でも みられる事実で，粘板岩の粉砕されやすい性質があ ることを示している。

10 物 部 川

物部川でば高知県香 美郡土佐山田町神母木 から，同郡吉川村吉原 にいたる約 $9.5 \mathrm{~km} の$ 地域で測定を行なつた。 測定区域における諸要 素は第 12 図のごとく である。これによる と，第 1 地点には 512 〜256 mm といつた巨 礫が存在するが，第 2 地点で見当らず，両地 点の間で粒径はかなり
粒径ダイヤグラム

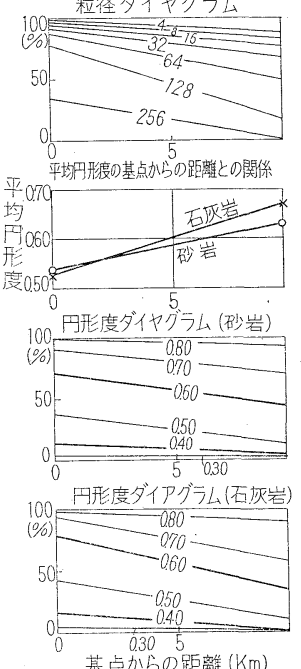

第 12 図 物部川

30）前揭 3) 
減小していることがわかる。

この河川の上流地域に求ける地質は，高知買より 発行された $1 / 20$ 万高知紧地質鉱産図で詳細にわか る。これによると，物部川の上流地域における主な 地層は，秩父古生層の虚空蔵及び高岡層，中生代三 畳紀の大杤層，白亜紀の葉山塬などである。これら

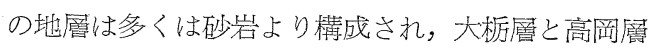
の一部に石灰岩が含まれている.

このような地層の分布状態から，石灰岩戀の大部 分は第 1 地点と最上流地域との中間地域から供給さ れ，最上地域から供給されるものは，ごく一部にす ぎないことがわかる。これに対し，砂岩磦は第 1 地 点より上流の全地域から供給される。このような分 布から，第 1 地点に於ける砂岩緗は円䃯が多い反面， あまり磨滅を受けない角礫・亜角礫もかなり多いも のと考えられる.しかし，奏際には砂岩・石灰岩樂

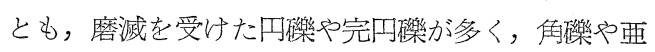
角礫が少ない。この河川の上流部における運搬距離 が，他の河川にくらべて比較的短かいにもかかわら ず32)，このように円形化されたものが多いのは，如 何なる理由によるのか不明である。

測定区域では，砂岩礫も石灰岩睒樂も，それぞれ平 均円形度はかなり急激に增加している。この場合， とくに石灰岩䃯の円形化が著しく，第 2 地点では今 回の調査では最も高い 0.67 という值を示してい る33). 石灰岩の円形度ダィヤグラムによると，第 1 地点から第 2 地点の開で, 0.60 を中心として, 急激 にその割合が変つている. 0.60 付近のものは，ほと んど角稜がないにかかわらず，このように磨滅によ つて円形化が進むのは，石灰岩が粘板岩や頁吡とは 異なり，粉砕や分裂せずに，急速に磨隇していくこ
とを示すものである。

\section{IV 平均円形度の变化とその原因について}

平均円形度と運㮽距離とは，前述のごとく，河川 によつて，或いは礫質によつて，いろいろ異なつて いる。この原因については，筆者は既に勾配・砂量 等が，かなり大きな影響力をもつていることを明ら かにした
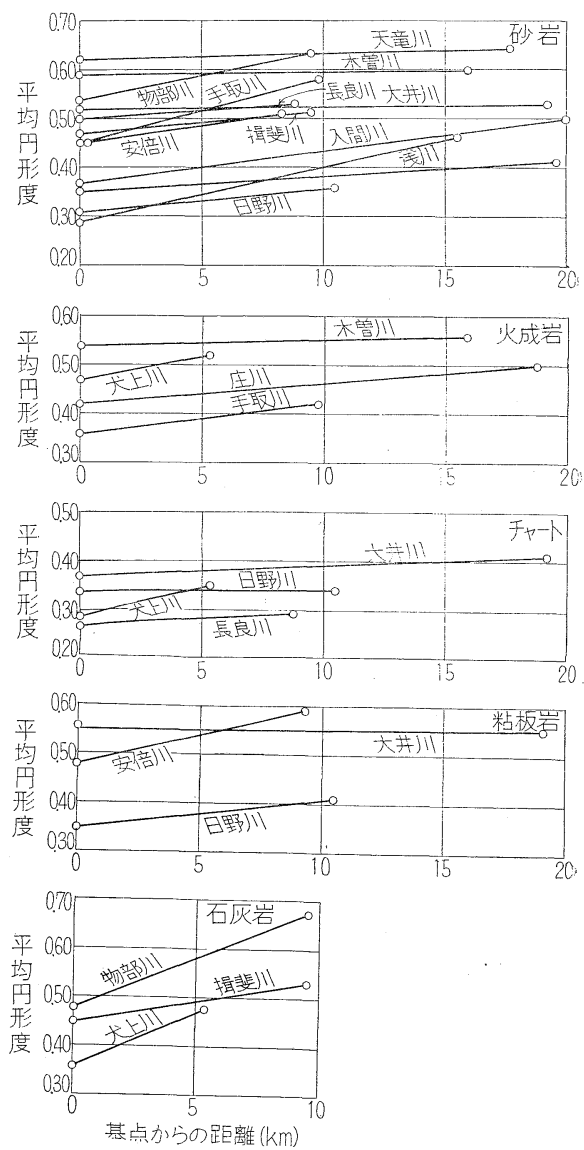

第 13 図 礫質別各河川に打ける平均 円形度の変化

31）高知県 (1961) : 高知県地質鉱産図説明書.

32）物部川における第 1 地点から最上流部までの延長距離は約 $25 \mathrm{~km}$ ある。これは，大井川の約 $90 \mathrm{~km} ，$ 長 良川の約 $60 \mathrm{~km}$ からみると，かなり短かいが，平均円形度はこれらの河川より高い.

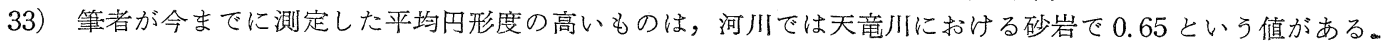
34）前揭 3) 
らに多くの河川を比較研究し，ょり明確な原因の究 明を行なつてみた。

いま，各河川における平均円形度と運搬距離との 関係学砂岩・頁岩・チャート・石灰岩・头成岩につ いてまとめると，第 13 図のごとくなる。このうち 砂岩35の和には，以前この礫質で研究した，浅川・ 大間川・天竜川・野洲川の結果を加えた。この図か らチャート・火成岩などによる差異は少なく，真 岩・石灰岩・砂岩などは河川による差異は大きいこ とがわかる。このことから，各河川の比較には，頁 岩・石灰岩・砂岩など，相対的に抵抗の弱いものを 用いたらよいことがわかる。これらのうち，砂岩は その分布する河川の数む多いので，これを中心とし て考察を行なつてみた。

第 13 図によつて気づくことは，第1地点に打け る平均円形度の高低は，その後の変化とは関係がな いことである。すなわち日野川のように，平均円形 度が低くても；変化のほとんどないものもあるし。 物部川のように高くてもかなり急激な変化を示す場 合もある。これは平均円形度の変化が直線的である こととも関係があり，礫の供給地が非常に多いこと， 運搬砂礫量が多いこと，運搬の場合個々の硣が移動 するような型式をとらないことなどが原因と思われ る。このようにみると，平野河川に打ける平均円形 度の変化は，各河川のもつ性質によつて，いろいろ 異なると考えてよいようである。

円形度に影響を与えるものとしては，河床勾配・ 砂砅の割合のほか，岩石の性質・粒径・流速・堆積 中の化学的風化・霜の作用・運搬距離・波の作用 ${ }^{36)}$.

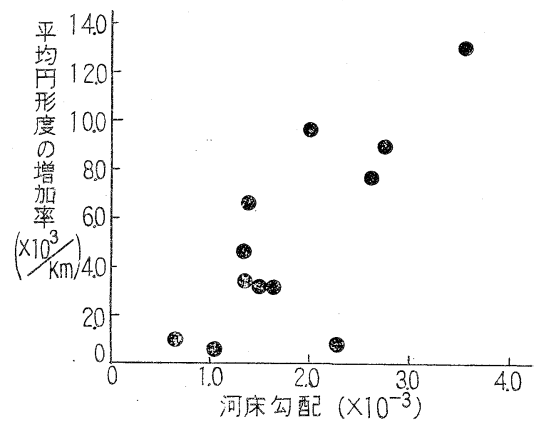

第 14 図河床勾配と平均円形度の増 加率との関稉

乱流37などがあげられている。これら諸因子のうち。 本研究では，化学的風化・霜の作用・波の作用など はほとんど考える必要がなく，また運搬距離・岩石 の性質・粒径等も一応明らかなので，その他の因子 について調べてみた。

まず，円形良に最も大きな影響をもつ，河床勾配 について考察を行なつた。すなわち測定区閒に执け る河床公配と， $\mathrm{km}$ 当りの平均四形度の増加量との 関係をまとめると，第 14 図のごとくなる．この図 によると，大井川を除けば，全体として，河床勾配 が急になるにしたがい，円形度の増加量が高くなる ことが明瞭である。このように，河川勾配が急な河 川ほど，砶が急激に磨隇するのは，以前の研究で考 察したような38)，河床勾配が急になると，流速が早 くなることも原因の 1 つであろうが，それより河の

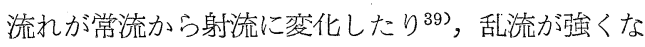
つたりするため，砶が個々に運搬される機会が多く なることのほうが，より大きな原因となるのではな， かろらか.

35）ここでいう砂岩は全部硬砂岩である。したがつて，従来研究した浅川・大閒川・天竜川・野洲川の結果 と比較研究することができる.

36）前揭 7）

37) Tricart, J. and Schaffer, R. (1950) : L'indice d'émousé des galets, moyeu d' étude des systèmes, d'érosion, Rev. Geomorphologie Dynamique, 4, kp. 151 179.

38）前揭 3)

39）木下良作の実験では，勾配が $1 / 200$ 程度になると，常流から射流に変るという。 
第 15 図平均砂量円形度の 増加率々の関㮇

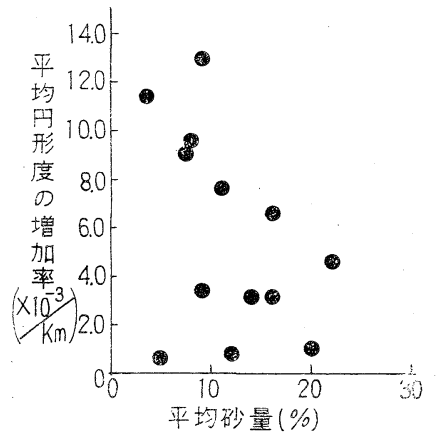

ただ，大井川 のみは，河床勾 配が $4.6 \times 10^{-3}$ と比較的急勾配 を示すにもかか わらず，平均円 形度の変化は非 常にわずかであ る.この原因に ついてはろい ろあるらが，䈉 者等は大井川の 河川巾員が，流量の割合に広いことが，大きく作用 しているのではないかと考えている。すなわち，測 定区間に打ける大井川の平均河川巾員は第 1 表のご とくで，流域面積の 8～4倍も大きな木曾川・天竜 川より河ウが広い40)。このため，大井川では洪水時 でも此較的水深は浅く，乱流の釷直分力は弱く ${ }^{411}$, 礫の個々の移動が行なわれないため，円形度が変化 しないのではなからうか。

次に円形度の变化と，砂㗂の割合との関係につい て，考察を行なつてみた、いま平均砂量422と平均円 形度の増加率との関係は，第 15 図のごとくなる。 この困によると，各点はちらばつていて，一定の傾 向はつかめない。しかし，一般にそのバラッキは， 砂量の少ないものほど大きいようであるから，大ま かにいえば，前の研究で考察したように，砂量の多 いるのほど，円形度の増加量は少なくなることが考 えられる. 結局, この関係は，前述の河床勾配の場
合より，あまり明瞭ではない。従来，砂の割合は礫 の磨隇に対する重要な因子と考えられてきたが，以 上の例加りわかるように，普通一般の河川におけ る $10 \%$ 程度の砂量の差では，あまり大きな影響力 がないのではなからうか。

\section{V 河川堆積物の粒径変化に含まれる磨滅の割合}

円形度の変化は，采の磨隇を意味することになる ので，円形度と磨滅量との関係を利用して，各河川 における磨隇の割合を推定した。この場合推定方法 としては，Kuenen の実験結果を用いた43)。これは 円形度と重量の減少量との関係安求めたものである。 もちろん，同じ円形度を示すものが，同じ割合で重 量を失うとは限らないが，Kuenen の結果は，両者 の平均的なものと考えられるので，この結果を使用 することにした。このようにして得た結果は，第 2 表のごとくである。

この表によると，重量の減少量は，河川の勾配・ 運搬距離・流量あるいは礫質によつていろいろ異る が，わが国では平均して，渓口までで $7 \% ，$ 河口あ るいは礫質の分布限界付近までで $9 \%$ あり，した がつて，平野部分では $2 \%$ 程度であることがわかる。 それゆえに,わが国においては,河川における礫の磨 滅は，渓口まででそのほとんど大部分は終り，それ より下流では著しく磨隇しないものと考えられる 単位距離あたりの減少率は，Daubrée ${ }^{45)} や ， K u-$ enen ${ }^{46)}$ の実験結果以外は，乏までに実際の河川で， 測定または推定したものはなく，比較することはむ ずかしい，しかし，第 2 表の值は；これらの奏験結

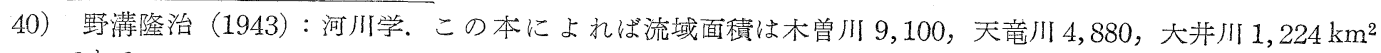
である。

41） Bourcart, J. (1957) : l'Erosion des contineuts（照田省子訳：侵蝕論）

42）前揭 3). 43） 前揭 7)

44）中山正民（1962）：熊野浦における海浜堆積物について，地理評，35，606〜617. 河口まで運蒰された磷 が，波の作用によつて，海岸沿いに運搬される場合は，磨滅量は著しく大きい。このことから，礫の磨滅 が大きい順にならべると，海浜，溪谷，平野河川となる. 
第 2 表 測定河川における磁質別の重量減少率

\begin{tabular}{|c|c|c|c|c|c|c|c|}
\hline 河 川 名 & 磸 質 & $\begin{array}{l}\text { 起点に抒ける } \\
\text { 平均円形度 }\end{array}$ & 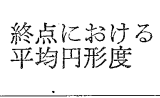 & $\begin{array}{r}\text { 起点に抒ける } \\
\text { 重量減少率 } \\
\text { (A) }\end{array}$ & $\begin{array}{r}\text { 終点に㧍ける } \\
\text { 重量減少率 } \\
\text { (B) }\end{array}$ & $B-A$ & $(\mathrm{~B}-\mathrm{A}) / \mathrm{km}$ \\
\hline 安 倍 川 & $\begin{array}{l}\text { 粘板岩 } \\
\text { 砂 岩 }\end{array}$ & $\begin{array}{l}0.48 \\
0.45\end{array}$ & $\begin{array}{l}0.58 \\
0.52\end{array}$ & $\begin{array}{l}8 \% \\
7\end{array}$ & $\begin{array}{c}12 \% \\
9\end{array}$ & $\begin{array}{l}4 \% \\
2\end{array}$ & $\begin{array}{l}0.47 \% \\
0.22\end{array}$ \\
\hline 大 井 川 & $\begin{array}{l}\text { 頁 岩 } \\
\text { 砂 岩 } \\
\text { チャート }\end{array}$ & $\begin{array}{l}0.56 \\
5.52 \\
0.37\end{array}$ & $\begin{array}{l}0.55 \\
0.53 \\
0.42\end{array}$ & $\begin{array}{r}10 \\
9 \\
5\end{array}$ & $\begin{array}{r}10 \\
9 \\
6\end{array}$ & $\begin{array}{l}0 \\
0 \\
1\end{array}$ & $\begin{array}{l}0.00 \\
0.00 \\
0.07\end{array}$ \\
\hline 木 兽 川 & $\begin{array}{l}\text { 砂 岩 } \\
\text { 石英斑岩 }\end{array}$ & $\begin{array}{l}0.59 \\
0.54\end{array}$ & $\begin{array}{l}0.60 \\
0.56\end{array}$ & $\begin{array}{l}12 \\
10\end{array}$ & $\begin{array}{l}12 \\
10\end{array}$ & $\begin{array}{l}0 \\
0\end{array}$ & $\begin{array}{l}0.00 \\
0.00\end{array}$ \\
\hline 長 良 川 & $\begin{array}{l}\text { 砂 岩 } \\
\text { チャート }\end{array}$ & $\begin{array}{l}0.50 \\
0.27\end{array}$ & $\begin{array}{l}0.53 \\
0.29\end{array}$ & $\begin{array}{l}8 \\
3\end{array}$ & $\begin{array}{l}9 \\
3\end{array}$ & $\begin{array}{l}1 \\
0\end{array}$ & $\begin{array}{l}0.18 \\
0.00\end{array}$ \\
\hline 揖 斐 川 & $\begin{array}{l}\text { 砂 岩 } \\
\text { 石 灭岩 }\end{array}$ & $\begin{array}{l}0.46 \\
0.45\end{array}$ & $\begin{array}{l}0.51 \\
0.53\end{array}$ & $\begin{array}{l}7 \\
7\end{array}$ & $\begin{array}{l}9 \\
9\end{array}$ & $\begin{array}{l}2 \\
2\end{array}$ & $\begin{array}{l}0.21 \\
0.21\end{array}$ \\
\hline 庄 川 & 花崗岩 & 0.42 & 0.50 & 6 & 8 & 2 & 0.16 \\
\hline 手 取 川 & $\begin{array}{l}\text { 砂岩 } \\
\text { 流紋 岩 }\end{array}$ & $\begin{array}{l}0.45 \\
0.36\end{array}$ & $\begin{array}{l}0.57 \\
0.42\end{array}$ & $\begin{array}{l}7 \\
5\end{array}$ & $\begin{array}{r}10 \\
6 \\
\end{array}$ & $\begin{array}{l}3 \\
1\end{array}$ & $\begin{array}{l}0.31 \\
0.10\end{array}$ \\
\hline 犬 上 川 & $\begin{array}{l}\text { 石英斑岩 } \\
\text { 石灰 岩 } \\
\text { チャート }\end{array}$ & $\begin{array}{l}0.47 \\
0.36 \\
0.29\end{array}$ & $\begin{array}{l}0.52 \\
0.48 \\
0.35\end{array}$ & $\begin{array}{l}7 \\
5 \\
3\end{array}$ & $\begin{array}{l}9 \\
8 \\
4\end{array}$ & $\begin{array}{l}2 \\
3 \\
1\end{array}$ & $\begin{array}{l}0.38 \\
0.57 \\
0.19\end{array}$ \\
\hline 日 野 川 & $\begin{array}{l}\text { 粘板岩 } \\
\text { 砂 岩 } \\
\text { チャート }\end{array}$ & $\begin{array}{l}0.35 \\
0.32 \\
0.34\end{array}$ & $\begin{array}{l}0.42 \\
0.36 \\
0.34\end{array}$ & $\begin{array}{l}4 \\
4 \\
4\end{array}$ & $\begin{array}{l}6 \\
5 \\
4\end{array}$ & $\begin{array}{l}2 \\
1 \\
0\end{array}$ & $\begin{array}{l}0.19 \\
0.10 \\
0.00\end{array}$ \\
\hline 物 部 川 & $\begin{array}{l}\text { 砂 岩 } \\
\text { 石岑 岩 }\end{array}$ & $\begin{array}{l}0.54 \\
0.53\end{array}$ & $\begin{array}{l}0.63 \\
0.67\end{array}$ & $\begin{array}{r}10 \\
9\end{array}$ & $\begin{array}{l}15 \\
22\end{array}$ & $\begin{array}{r}5 \\
13\end{array}$ & $\begin{array}{l}0.53 \\
1.37\end{array}$ \\
\hline
\end{tabular}

果と基本線ではよく一致しており，かなり信用にた るものと思われる。いまこれらのうち，最も事例の 多い砂岩の場合を，Kuenen の結果と比較すると， 物部川の值以外は，実験例より約 $1 / 2$ 程度小さい。 実際河川に批洪水期の流速 ${ }^{47}$ から考えると，害 際河川のほうが，実験の場合よりかなり減少率が多 くなるはずである。しかし，事実は反対で，河川に おいてはこのようにその值は小さい。このことは実 際の河川に抢ける砂磁の運搬形態が，実験の場合の ように，一個一個の礫が常に移動しているような，
単純な形態でないことを示すものであろう。

次にこのような磨隇率が，河川に打ける砂租の 粒径減小に対して，ぞの程度の役割をはたしている かを推定してみた。従来，河川に括ける節分作用と 磨滅作用との割合については，いくつかの研究が行 なわれ，いろいろの值が出されている48449. しかし， 今までに行なわれたものは，実験や $2 \sim 3$ の河川に 抢ける結果，あるいは1２種の礫質にすぎない， これに対して, 本研究では測定河川の数も多く，ま た礫質の数も多いので，推定結果はかなり一般的な

45）前揭 6). 46） 前揭 7）

47）河床勾配の緩い野洲川でも $4.0 \mathrm{~m} / \mathrm{sec} と い う$ 值が報告されている。これは実験の最高よりかなり速い.

48) Plumley, W. J. (1948) : Black Hills terrace gravels: A study in sediments transport, Jour. Geol., 56, $525 \sim 577$. 
第 3 表 粒径変化に含まれる磨滅量の割合

\begin{tabular}{|c|c|c|c|c|c|}
\hline 河川名 & $\begin{array}{l}\text { 起点の粒径 } \\
\text { (a) } \mathrm{mm}\end{array}$ & $\begin{array}{l}\text { 終点の粒径 } \\
\text { (b) } \mathrm{mm}\end{array}$ & $\begin{array}{l}\text { 粒径減少率 } \\
\text { (c) \% }\end{array}$ & $\begin{array}{l}\text { 円形度から } \\
\text { もとぬた粒 } \\
\text { 径減小率 } \\
\text { (d) } \%\end{array}$ & $\mathrm{~d} / \mathrm{c}$ \\
\hline 安倍川 & 64 & 56 & 12.5 & 1.40 & 11. 2 \\
\hline 大井川 & 90 & 32 & 64.5 & 0.89 & 1.4 \\
\hline 木曾川 & 250 & 56 & 77.5 & 0.00 & 0.0 \\
\hline 長良川 & 165 & 69 & 58.1 & 0.79 & 1.4 \\
\hline 揖斐川 & 105 & 49 & 53.3 & 1.26 & 2.4 \\
\hline 庄 川 & 420 & 51 & 88.0 & 1.26 & 1.4 \\
\hline 手取川 & 580 & 140 & 75.9 & 1.26 & 1.7 \\
\hline 犬上川 & 69 & 21 & 69.6 & 1.26 & 1.8 \\
\hline 日野川 & 48 & 23 & 52.1 & 1.09 & 2.1 \\
\hline 物部川 & 205 & 64 & 68.9 & 2.08 & 3.0 \\
\hline
\end{tabular}

合がどのように異るかを調べた。 そこでここれらの結果をまとめ， 磨滅作用に対する，抵抗の強い ものからの序列を作成してみた。 もち万ん，同じ岩質でも，時 代・産状・管理の多少などによ つて，磨滅作用に対する抵抗は かなり異なることが考えられる。 しかし，それらを平均するなら ば，そこにはやはり岩質による 序列があると思われる。

比較の場合，測定した河川全部 から，各岩質にわたる，磨滅作用に対する抵抗の強 弱をきめる事例はないのでまず最も多くの河川に みられる砂岩を基淮として，これょり抵抗の強い岩 質と，抵抗の弱い岩質とに大別した。これによると，

（イ）砂岩より抵抗の強、岩質……チャート・石 英斑岩・流紋岩

（口）砂岩より抵抗の弱い岩質……花崗岩・頁 岩・粘板岩・石灰岩

このように分けたものを，各グループ内で比較す ることになるが，もちろんこの場合も事例がないの で，直接決定することはできない，そこで閒接的方 法によつて決めることにした。石英斑岩と流紋岩と は，同系統の䂢であるから，その磨隇作用に対する 抵抗性は，一応同じであると考えた。

次に，2つの岩質が同じ距離だけ運搬された場合 と考えられる，大井川におけるチャートと砂岩，木 曾川における石英球岩と砂岩の平均円形度の差を比 較した。これによると，大井川は木曽川に比べて。 相対的に運搬距離は短いが，チャートと砂岩との平 均円形度の差は 0.10 程度ある.これに対して，木 曽川における石英斑岩と砂岩の平均円形度の差は，

以上，各河川において，岩質によつて，磨滅の割

49) Krumbein, W. C. and Sloss, L. L. (1953) : Stratigraphy and Sedimentation.

50）前揭 3） 


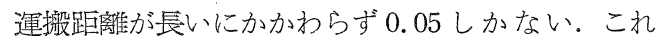

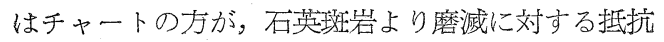
性が強いためと考えた。したがつて，砂岩より抵抗 の強い岩質を，強い順にならべると，チャート・石 英斑岩・流紋岩となる。

砂岩より抵抗の弱い岩質も, 相互の関係を知る事 例がないので，直接比較することができない、しか し，物部川や揖斐川などの場合からもわかるように， 石灰岩は砂岩に比して，磨滅作用に対する抵抗は弱 く，急激にその差が大きくなる。これに対し，頁岩 や粘板岩は，大㚏川・安倍川・日野川などでみられ るように，砂岩よりやや大きいぐらいである。した がつて，頁岩や粘板岩のほうが，石灰岩より磨滅さ れやすいと考えることができる.

花崗岩と頁岩や石灰岩については, 現在のところ 比較すべき資料がない。しかし，庄川でみられるよ ろに，砂岩と同じかそれよりやや弱いこと，円礫が ある一方，角礫もあるといつたことなどから，一応 砂岩と頁岩や粘板岩との間にくると考えた。これら のことから；砂些より抵抗の弱、岩石を，抵抗の強 い順にならべると，砂岩・花崗岩・頁岩・石灰岩と なる・

以上の結果より両者をまとめ, 抵抗の強い順にな らべると，チャート・石英斑岩・流紋岩・硬砂岩・ 花菵岩・頁岩・粘板岩・石灰岩となる。これはKuenen ${ }^{51)}$ が求めた順序にほぼ似ており，かなり正確な ものであると思われる。

\section{VII 結、語}

以上，河川の平野部で，各種の繰について，円形 度の変化とその原因を考察した結果をむとめると， 次の如くなる.

（1）砂礫の磨隇は，河床勾配に左右される場合
が多く，河床勾配の急な河川ほど急速に進み，河床 勾配の緩やかな河川では，かなり長い距離運搬され ても，磨滅は進行しない。しかし，大井川のような， 比較的流域面積が狭く，それに対する河巾の広い河 川では，河床勾配の急なわりに，磨隇はあまり進ま ず，磨滅が流速よりも，流れの变化や乱流の強さな どに関係することを示している。

（2）砂礫の割合は，河床勾配ほど，礫の磨隇に 対しては影響を与えていない。これは，今回測定を 行なつた，河川における砂の割合の差異がわずか 10 \%程度にすぎないことも，原因の1つと考えられる。 従来, 各種の研究で考察された，砂の割合の多少と いうことは，砂が全くないとか，砂が非常に多いと かいう基準で考察されていたようであり，砂が礫の 磨滅に対して眀瞭な影響をもつ場合は，少なくとも $20 \%$ 以上差がないと，つかめないのではあるまい 力.

（3）同じ河川区域でも，礫の磨隇過程は，また 岩質によつて異なる。磨隇作用に対する抵抗を，強 い岩質の順にならべると，チャート・石英斑岩・流 紋岩・硬砂岩・花崗岩・頁岩・粘板岩・石灭岩とな る。これらのうち，砂岩より抵抗の強い岩石は，骐 削作用や研磨作用によつて，少しずつすり減つて行 くが，花崗岩・粘板岩のように抵抗の弱い岩質の礫 は，少しずつすり減つて行く反面，䃯相互の衝突に よつて，分裂・粉砕されるものも多い。

（4） 口形度をもとにして，礫の重量減少率を推 定すると，平均して，渓口までで $7 \% ，$ 平野に扮け る礫の分布限界までで，9\%となる.したがつて， 河川の平野部における礫の重量減少率は，わずか 2 \%にすぎないこのことから，平野部分における堆 積物の急速なる粒径変化は，節分作用によるものと 考えられる．推定の結果によると，その $98 \%$ 穊

51）前揭 7). Kuenen は, 抵抗の強いものから順に，チャート・石英・石英斑岩・硬砂岩・深成岩・火成岩・ 石死岩・砂岩・熔岩・片麻岩・片岩とした。 


\section{ROUNDNESS OF PEBBLES IN THE COURSE OF RIVERS IN JAPAN Masatami NAKAYAMA and Toshihiko MIURA}

The roundness of pebbles has been measured for the purpose of finding the effects by abrasion and transportation in streams. In the lower course of ten rivers: the Abe, Oi, Kiso, Nagara, Ibi, Sho, Tedori Rivers in the Chubu District, and the Inugami, Hino Rivers in the Kinki District and Monobe River in the Shikoku District, two or three stations were chosen for sampling the pebble population, where we have measured the size of sediment and roundness of pebbles $32-64 \mathrm{~mm}$ each of some kinds of rock types. The results obtained for these values are given in figures 3 to 13 shown by mean size, mean roundness, and ratio of roundness in each rock type with distance of transport. From these figures we considered the cause of abrasive action accompanying transportation. Their results are as follows:

(1) On the relationship between roundness of pebbles and distance of transport in the same rivers, it is clear that the roundness differs with rock types. For example, it is clearly shown that the roundness of limestone is to increase rapidly downstream, but that of chert little changes is the roundness. The analysis of roundness diagram which shows the relation between ratio of roundness and distance of transport explains the abrading processes. Hard rock, such as chert, quartz-porphyry, liparite or graywacke, is worn mainly by chipping and grinding. On the other hand, soft rock such as granite, slate and shale, brings about the exfoliation, and is worn more by splitting and crushing than hard rock.

(2) This study of the roundness of pebbles, by means of using graywacke which is found in many rivers, shows that the steeper the gradient of the river floor is, the more the roundness of pebbles is. The cause seems to be a rapid flow, variation from streaming to shooting in a stream form or increase in the intensity of turbulence on the steeper gradient of a river. But, on the Oi River the mean roundness shows no change downstream in spite of the steep gradient of the river floor. This may be that turbulence weakens the attrition of pebbles, as the river is wide downstream.

(3) The ratio of the loss in the weight of pebbles varies with the river property, distance of transportation, and rock type. In the estimation by roundness, it seems that the loss in the weight of pebbles is about 7 per cent as far as the mouth of a canyon and 9 per cent as far as the mouth of a river in Japan. Moreover, on the basis of the results obtained from the estimation, selective transport accounts for 98 per cent of the size decrease and 2 per cent is accounted for by abrasion in the lower course of the river in Japan.

(4) The ratio of gravel to sand in sediment has not so much effect on the attrition of pebbles as gradient of the river floor. For one thing, it seems that the ratio of sand in sediment in the river in which the roundness is measured, is about 10 per cent in difference. But, the former studies are made in the river where there is found no sand or much sand. Therefore, the relation stated above is only found in an extremly different ratio of sand.

(5) The order of resistance for abrasion obtained from roundness is as follows : chert is heighly resistant, liparite, and quartz-porphyry are resistant, graywacke is moderate, granite, shale and slate are less resistant, and limestome is small. This order coincides to that of Kuenen's one. 